\title{
Market Service Retribution Optimization Strategy through the Root Cause Approach
}

\author{
Suparmono Suparmono $^{1 凶}$, Junaidi Junaidi $^{2}$, Suryanto Suryanto $^{3}$ \\ Sekolah Tinggi Ilmu Manajemen YKPN Yogyakarta, Indonesia ${ }^{1}$ \\ Universitas Tekonologi Yogyakarta, Indonesia ${ }^{2}$ \\ Universitas Negeri Surakarta, Indonesia ${ }^{3}$ \\ e-mail: suparmono@stimykpn.ac.id
}

\begin{abstract}
This article aims to analyze the problems that occur in the non-optimal acceptance of market service retribution and design optimization strategies in Kebumen Regency, Central Java Province. The analytical tool used to analyze the main problem is to use a root cause analysis (RCA) approach and SWOT Analysis. After being analyzed using RCA, the next step is to map out possible strategies to be applied in overcoming these problems with internal and external approaches. From the results of the analysis, it was found that the acceptance of market service retribution was not optimal due to the low awareness of traders in paying levies, the decline in economic activity due to the impact of the pandemic, and the development of modern markets whose regulation was a little late. On the other hand, the development of information technology has resulted in changes in people's shopping patterns through online shopping. This condition certainly needs to be overcome with the right strategy from the government while maintaining healthy competition and controlling modern market outlets. The contribution of this research is that the analysis is carried out comprehensively using several approaches, which are different from previous studies.
\end{abstract}

Keywords: retribution, optimization, RCA, modern market

\begin{abstract}
Abstrak
Artikel ini bertujuan untuk menganalisis permasalahan yang terjadi pada belum optimalnya penerimaan retribusi pelayanan pasar dan merancang strategi optimalisasi di Kabupaten Kebumen Provinsi Jawa Tengah. Alat analisis yang digunakan untuk menganalisis masalah utama adalah dengan menggunakan pendekatan root cause analysis (RCA) dan Analisis SWOT. Setelah dianalisis menggunakan RCA, langkah selanjutnya adalah memetakan kemungkinan strategi yang akan diterapkan dalam mengatasi permasalahan tersebut dengan pendekatan internal dan eksternal. Dari hasil analisis diketahui bahwa penerimaan retribusi jasa pasar belum optimal disebabkan oleh rendahnya kesadaran pedagang dalam membayar retribusi, menurunnya kegiatan ekonomi akibat dampak pandemi, dan berkembangnya pasar modern. yang regulasinya agak terlambat. Di sisi lain, perkembangan teknologi informasi telah mengakibatkan perubahan pola belanja masyarakat melalui belanja online. Kondisi ini tentunya perlu diatasi dengan strategi yang tepat dari pemerintah dengan tetap menjaga persaingan yang sehat dan menguasai gerai pasar modern. Kontribusi penelitian ini adalah analisis dilakukan secara komprehensif dengan menggunakan beberapa pendekatan yang berbeda dengan penelitian-penelitian sebelumnya.
\end{abstract}

Kata kunci: retribusi, optimalisasi, RCA, pasar modern 


\section{INTRODUCTION}

Regional financial sources that come from regional income include Regional Original Income (PAD), balancing funds and other income. The fundamental source of regional finance, owned and managed by local governments, is Regional Original Revenue (PAD) (Usman, 2017). In the macroeconomic framework, regional taxes and regional levies are sources of regional income whose values vary greatly, depending on regional conditions and potential. For this reason, efforts are needed to improve and optimize so that regional development can be realized with the ultimate goal of welfare for the population (Sujjapongse, 2005).

According to Law 28 of 2009 concerning Regional Taxes and Regional levies, regional levies are regional levies as payment for services or the granting of certain permits specifically provided and/or granted by the regional government for the benefit of individuals or entities. Regional levies are divided into three types, namely general service levies, business service levies and licensing fees (Listyaningrum et al., 2019).

By structuring and expanding the basis for regional taxes and levies, it is hoped that the region's ability to finance its expenditure needs will be greater because regions can increase regional original income according to the potential that exists in their respective regions. However, in reality, related to revenues sourced from PAD such as Regional Taxes, Regional Levies, Separated Regional Assets Management Results, and Other Legitimate Regional Original Income, some regions have not been able to optimize PAD due to the large gap between potential and targets set (Worumi, 2019).

This article aims to analyze the problems that occur in the non-optimal acceptance of market service fees and design optimization strategies in Kebumen Regency, Central Java Province. Market Service Charges, a levy is levied on services and the use of market facilities managed by the Regional Government. The object of market service retribution is the provision of traditional market facilities, in the form of courtyards, stalls, kiosks and market facilities and infrastructure managed by the Regional Government, and specifically provided for traders. The subject of market service retribution is an individual or entity that uses the services of market facilities in the market area. Mandatory market service levies are individuals or entities which, according to the provisions of the levy laws and regulations, are required to pay market service levies.

Of the two efforts to increase regional taxes and levies through intensification and extensification, their use must take into account the potentials they have as well as the situations and conditions faced by the organization. So before we discuss further about efforts to increase regional taxes and levies by market management institutions, it is necessary to first understand the concept of organization (Purnomo et al., 2019).

\section{RESEARCH METHOD}

To achieve the objectives set out in the previous section, the analytical tools used in this study are SWOT and RCA..

SWOT analysis (Strengths, Opportunities, Weaknesses, Threats). This analysis attempts to integrate the interaction between internal factors in the form of strengths and weaknesses as well as external factors in the form of opportunities and threats to then be formulated into relevant strategies in order to achieve goals (Saqib, 2017; Vu \& Pham, 2016). According to this analysis is based on a logic that can maximize strengths and opportunities and simultaneously minimize weaknesses and threats (Khairunnisa, 2011; Kusnedi, 2018).

RCA is a gradual analysis technique that focuses on finding the root cause of a problem, and not just looking at the symptoms of a problem (Croes et al., 2020; Hidayat et al., 2020). The purpose of RCA is to find (a) what actually happened; (b) why did this problem occur; and (c) what 
can be done to prevent this problem from happening again in the future.

\section{RESULT AND DISCUSSION}

From the value of the regional retribution, the regional retribution managed by the Department of Industry and Commerce of Kebumen Regency is the Market Service Retribution, Cleaning Retribution, and Special Parking Fees. Of the three types of retribution, judging by their performance from 2015 to 2020, the level of performance achievement is still fluctuating, this is due to several reasons, including the occurrence of the COVID-19 pandemic that hit in the last two years. Nevertheless, the achievement level in 2020 for these three types of retribution, the value of performance achievement is 103.9 percent. In detail, Market Service Charges, Cleanliness Fees, and Special Parking Charges can be seen in Table 1 .

Table 1. Kebumen Regency Market Service Charges and Targets

\begin{tabular}{cccc}
\hline Year & Target & Realisation & \% \\
\hline 2015 & 4.970 .000 .000 & 4.578 .648 .900 & 92,13 \\
2016 & 3.204 .317 .000 & 3.306 .795 .300 & 103,2 \\
2017 & 3.185 .757 .000 & 3.554 .840 .700 & 111,6 \\
2018 & 4.320 .600 .000 & 3.850 .405 .650 & 89,12 \\
2019 & 5.543 .057 .800 & 3.997 .763 .750 & 72,12 \\
2020 & 8.506 .222 .000 & 8.833 .817 .950 & 103,9 \\
\hline \multicolumn{4}{l}{ Source: Department of Industry and Trade, Kebumen Region, 2021. }
\end{tabular}

Three types of retribution under the management of the Department of Industry and Trade of Kebumen Regency, market service retribution is still one type of retribution that contributes to Kebumen Regency's revenue. On the other hand, the amount of this retribution can still be increased by several strategies, both internally making improvements and controlling external conditions.

In determining the potential in each market in Kebumen Regency, many aspects are taken into account in determining rational and achieveable potential for the Kebumen Regency Government. Assumptions and the availability of supporting data accuracy are required in calculating the potential. Some notes for the accuracy of the data on the estimation of the potential market service retribution are (a) Identification and actual calculation of the number of kiosks and stalls in each regional market, (b) Identify the number of stalls and stalls that are stalled and not utilized by the tenants who entered into the initial contract, (c) Calculation of the number of kiosks and stalls that have not paid rent for kiosks and stalls and other obligations, and (d) In order to optimize it, it is necessary to periodically review related to market service retribution rates taking into account the ability to pay of traders.

From the results of the identification of internal factors consisting of strengths and weaknesses and identification of external factors consisting of opportunities and threats related to traditional market management and market service retribution problems, it can be determined the form of strategy required from the combination of these internal and external factors. The combination of these strategies is an alternative form that can be taken by stakeholders, in this case the Department of Industry and Trade of Kebumen Regency.

By using root cause analysis, broadly speaking, there are 6 main problems in managing traditional markets in Kebumen Regency, where each problem allows for other problems and is related between problems.

1. Changes in people's behavior in shopping in modern markets.

2. Limited budget to improve market infrastructure.

3. Limited human resources for collectors and market managers. 
4. The zoning of traders and the orderliness of traders create chaos in traditional markets.
5. Non-optimal acceptance of market service retribution due to low awareness of traders and lack of visitors.

6. Competition of traditional markets and modern markets

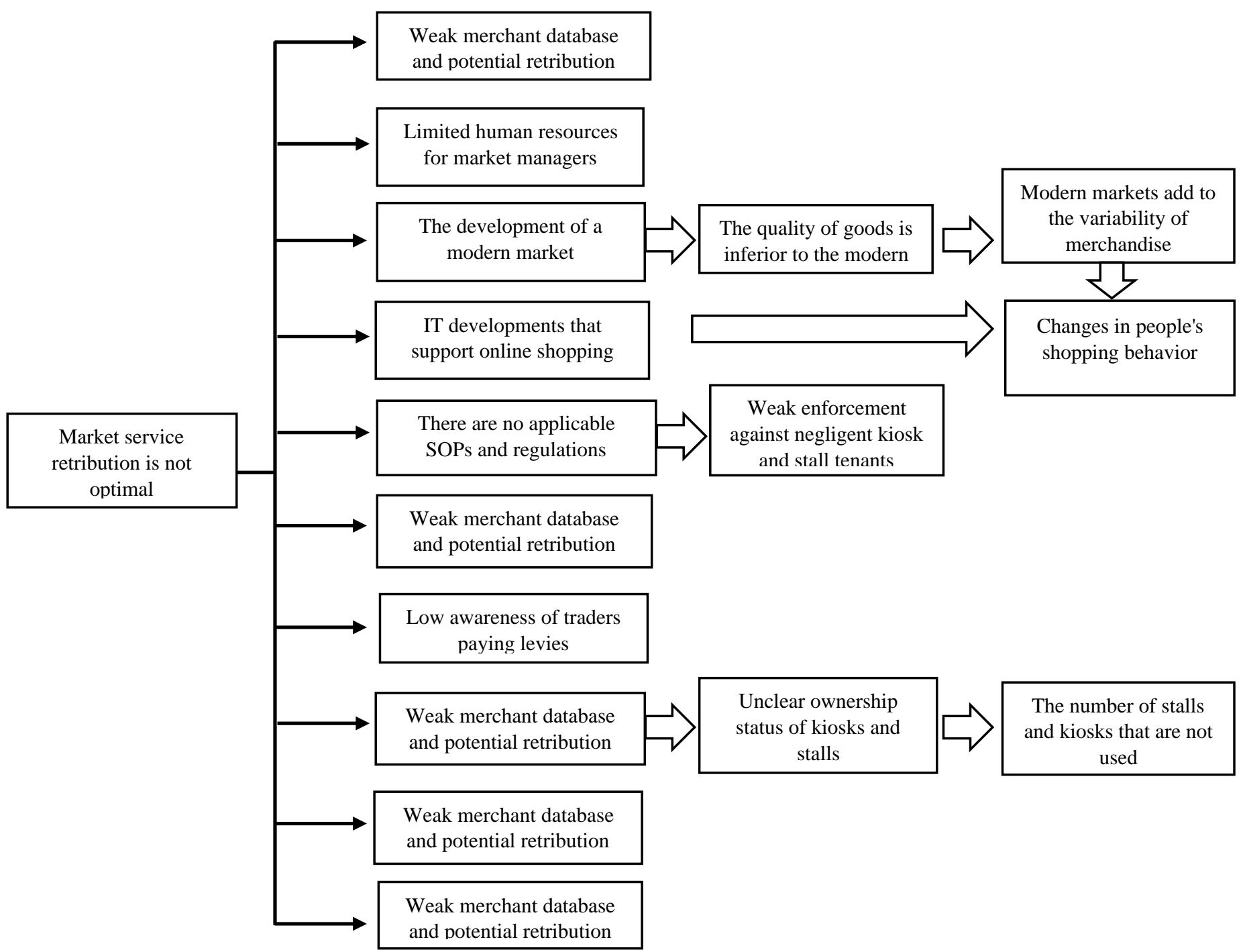

Figure 1. Root Problem Chart of Kebumen Regency Traditional Market Management 
Table 2. Traditional Market Development SWOT Matrix Analysis and Strategy in the Context of Increasing Kebumen Regency Market Service Fees

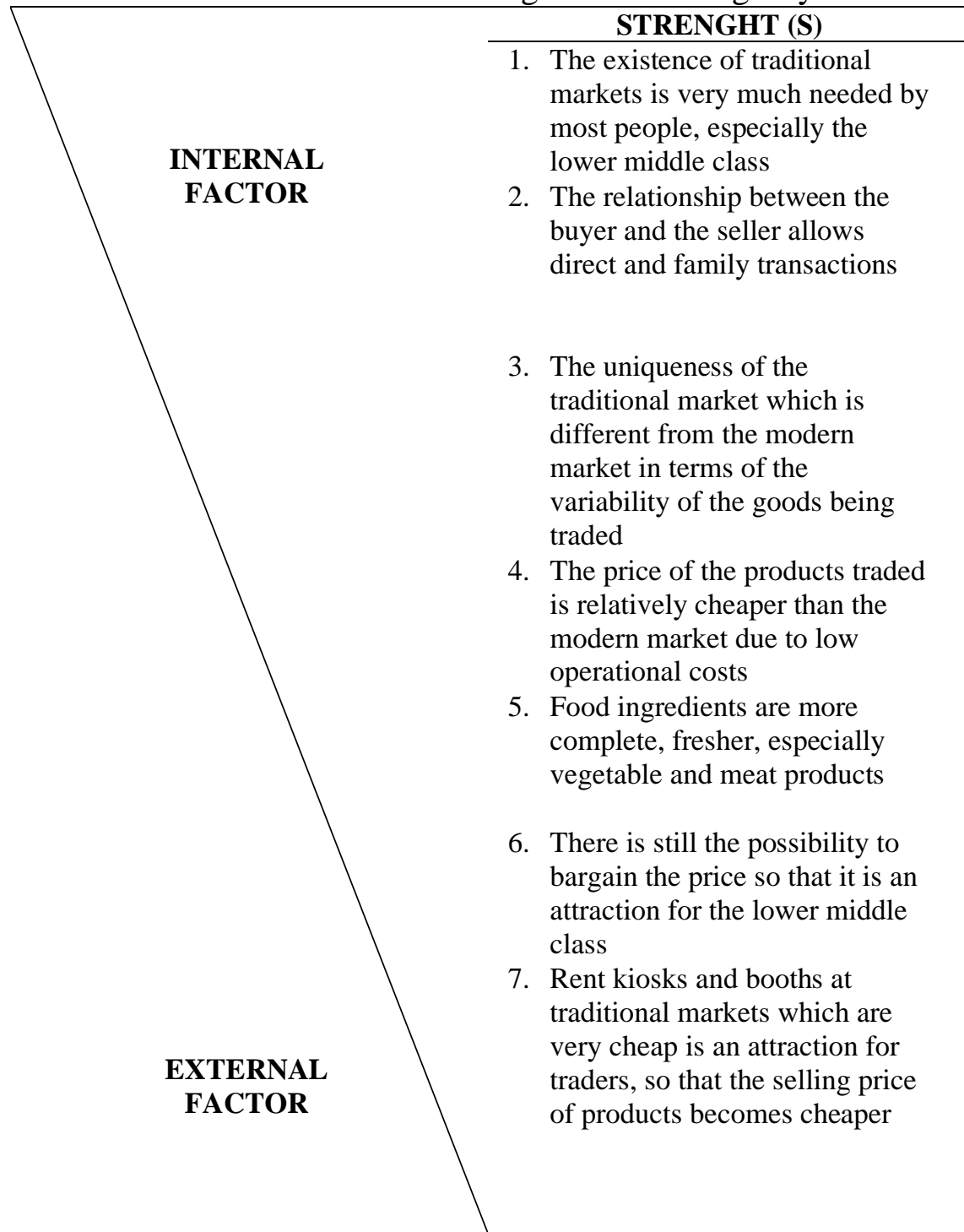

OPPORTUNITY (O)

1. There are still opportunities to increase PAD through other retributions in the market, such as parking fees, loading and unloading, use of toilets, and parking fees

2. The price of competitors' products, for example in the modern market is relatively more expensive

3. There is an allocation of funds and government attention to develop and revitalize traditional markets

1. Increasing the collection of human resources through training and technical guidance along with increasing the amount of retribution for market services

2. Increasing the accuracy of trader data which is updated periodically

3. Preparation of effective SOPs, starting from collecting data on traders, availability of kiosks and stalls, number of stalls, and

\section{WEAKNESS (W)}

1. Lack of human resources managing traditional markets and collecting human resources so that they are not optimal

2. Limited PAD in Kebumen Regency, so that funding for upgrading and repairing traditional market facilities and infrastructure is limited

3. High operational costs to carry out optimal collections and the impression of traditional markets that are less clean and unsafe

4. Awareness of traders to pay retribution is still lacking, due to uncertainty in the number of buyers in traditional markets

5. Zoning arrangements in managing traders resulted in traders emptying their stalls and stalls, they chose to trade outside the kiosk

6. There is no SOP, supervision, and socialization related to retribution obligations

7. Kiosks and stalls that are not occupied according to the tenant's data, making it difficult to collect and collect data

8. The quality of the goods sold is sometimes inconsistent in quality and price transfer of lease rights

4. Feasibility study regarding the alternative of appointing a third party to manage the market

5. The use of e-levies in collections for potential markets

STRATEGY (W-O)

1. Use of a barcode/digital system in collaboration with regional banks for payment of market service retribution

2. Improvement of supporting facilities that do not require large investments to increase the convenience of traditional markets

3. Data collection and zoning arrangements for kiosks and stalls based on the type of goods and ease of access for buyers

4. Identify and settle income arrears from tenants

5. Establish a market for certain products, vegetable market, fruit 
market, cassava market, meat market

6. The need to increase socialization and attract people to shop at traditional markets

\begin{tabular}{|c|c|c|}
\hline THREAT (T) & STRATEGY (S-T) & STRATEGY (W-T) \\
\hline $\begin{array}{l}\text { 1. The existence of a village market } \\
\text { that is far away and the growth of } \\
\text { household businesses, thereby } \\
\text { reducing the interest in buying } \\
\text { and selling in the market after the } \\
\text { market is revitalized }\end{array}$ & $\begin{array}{l}\text { 1. Coordination and } \\
\text { synchronization of policies } \\
\text { between OPD managing } \\
\text { traditional markets and village } \\
\text { markets so that they can } \\
\text { develop }\end{array}$ & $\begin{array}{l}\text { 1. Socialization to market traders } \\
\text { regarding the importance of levies } \\
\text { on PAD receipts and market } \\
\text { existence }\end{array}$ \\
\hline $\begin{array}{l}\text { 2. There is a shift in people's } \\
\text { behavior in shopping for daily } \\
\text { necessities due to the } \\
\text { development of modern markets } \\
\text { which are close to residential } \\
\text { areas }\end{array}$ & $\begin{array}{l}\text { 2. Non-physical revitalization of } \\
\text { traditional markets in the form } \\
\text { of improving cleanliness, } \\
\text { zoning and location of traders }\end{array}$ & $\begin{array}{l}\text { 2. Increasing the role of the market } \\
\text { head to increase user fees and } \\
\text { better market management }\end{array}$ \\
\hline $\begin{array}{l}\text { 3. Increasing number of modern } \\
\text { market outlets and online } \\
\text { shopping services }\end{array}$ & $\begin{array}{l}\text { 3. Control and regulation of the } \\
\text { number of modern market } \\
\text { outlets by considering the } \\
\text { existence of traditional markets }\end{array}$ & $\begin{array}{l}\text { 3. Campaigns from government } \\
\text { officials and community leaders to } \\
\text { shop at traditional markets }\end{array}$ \\
\hline $\begin{array}{l}\text { 4. Modern market outlets expand } \\
\text { and increase the types of goods } \\
\text { sold so that they can replace } \\
\text { modern markets }\end{array}$ & $\begin{array}{l}\text { 4. Forming and activating } \\
\text { merchant groups to facilitate } \\
\text { collection of market service } \\
\text { retributions and accommodate } \\
\text { the needs of traders }\end{array}$ & $\begin{array}{l}\text { 4. Policies regarding sanctions for } \\
\text { traders who are not disciplined in } \\
\text { paying retribution }\end{array}$ \\
\hline $\begin{array}{l}\text { 5. There are too many traders while } \\
\text { there are few buyers, it is difficult } \\
\text { to manage traders outside of } \\
\text { kiosks and stalls }\end{array}$ & $\begin{array}{l}\text { 5. Develop the market through the } \\
\text { main agricultural product } \\
\text { market as a wholesale center for } \\
\text { businesses in Kebumen } \\
\text { Regency }\end{array}$ & $\begin{array}{l}\text { 5. Review local regulations regarding } \\
\text { market retribution for a maximum } \\
\text { of } 3 \text { years to accommodate changes } \\
\text { that occur }\end{array}$ \\
\hline $\begin{array}{l}\text { 6. Most of the markets in Kebumen } \\
\text { are geographically located in the } \\
\text { city center so they have to } \\
\text { compete with modern markets }\end{array}$ & $\begin{array}{l}\text { 6. Regulation and application of } \\
\text { regulations related to } \\
\text { competition between traditional } \\
\text { and modern markets }\end{array}$ & \\
\hline
\end{tabular}




\section{CONCLUSION}

The management of market service retribution in Kebumen Regency is not optimal due to many problems that affect it. These factors include:

a) The development of village markets and the development of modern markets which are located close to traditional markets

b) Low awareness of traders paying market service fees, weak data base of traders, making it difficult to calculate potential market service retribution in real terms

c) The occurrence of the Covid-19 pandemic which resulted in the limitation of market operations on the one hand and the fear of buyers coming to traditional markets.

d) Changes in people's behavior in shopping caused by the development of information technology that makes it easier to shop

e) Data collection on kiosk and stall tenants is still weak and results in unclear ownership status and users of kiosks and stalls as well as the number of stalled kiosks.

f) There is no standard operating procedure (SOP) for the management of market service retribution which is simple and easy to implement so that the management is not optimal

g) Not all market traders use a digital market service retribution payment system so that its implementation is still experiencing dualism. The development of information technology (IT) which has not been utilized by market traders in optimizing their sales.

The strategy for developing traditional market management can be done in the following ways:

a) Continuing the verification and validation of trader data in the market which is carried out at any time when there is a change in the users of the booth or kiosk. It aims to update data on the number of traders, the types of goods traded, and the occupancy rate of kiosks in the market in real time. Identify and improve the accuracy of the market service database.

b) Market services are a supporting factor for the smooth running of economic activities in the market. Clear SOPs between market managers, traders and market visitors will improve order and smooth market management activities.

c) Preparation and preparation of feasibility studies related to Market Management. A market feasibility study related to market management is carried out with the aim that market management activities are well directed and experience optimization. With the feasibility study of market management, it is expected to optimize the level of market revenue.

d) Program to Increase the Capacity of Human Resources for Market Service Retribution Managers and Supervisors. The capacity of human resources for managing market service retribution is needed to maintain order and improve the ability to manage market retribution. This can be done, among others, through training programs organized in collaboration with the government and higher education institutions.

e) Implementation and optimization of eretribution (management and payment) full of levies for potential markets. The application of e-retribution in terms of system improvement is part of market digitization, which is a form of innovation carried out by traditional markets. With e-retribution payments become easier, orderly, and transparent.

f) Identification and Regulatory Mapping related to increasing the role of traditional markets. This is necessary in order to improve the effectiveness, accuracy, and renewability of the policy itself, adjusted to the development of policies and the goals expected by the government in 
accordance with the demands of the times.

g) Revitalization and improvement of market services. Improving services and better access to the consumer community, as well as making the people's market a driving force for the regional economy.

\section{REFERENCES}

Croes, R., Ridderstaat, J., \& Shapoval, V. (2020). Extending tourism competitiveness to human development. Annals of Tourism Research, 80(October 2019), 102825.

Hidayat, I., Mulatsih, S., \& Rindayati, W. (2020). The Determinants of Inclusive Economic Growth in Yogyakarta. Jurnal Economia, 16(2), 200-210.

Khairunnisa, K. (2011). Pajak Hotel dan Pajak Restoran sebagai Sumber Pendapatan Asli Daerah (PAD) (Studi Kasus: Kota Bandung). Journal of Regional and City Planning, 22(3), 227.

Kusnedi. (2018). Penerimaan Pajak Hotel di Kabupaten Sambas.

Listyaningrum, N., Lestari, S. F., Riyanto, I. A., Cahyadi, A., \& Sulistyo, B. (2019). Strengthening Local Potential for Sustainable Economic Development in Bengkulu City. IOP Conference Series: Earth and Environmental Science, 338(1).
Purnomo, B. S., Prawira, I. Farida Adi, \& Firdaus, M. I. N. (2019). Analisis Potensi dan Efektifitas Pajak Hotel serta Faktor-Faktor yang Mempengaruhi Penerimaan Pajak Hotel di Kota Bandung. Substansi: Sumber Artikel Akuntansi Auditing Dan Keuangan Vokasi, 3(2), 154.

Saqib, M. (2017). Asian Economic and Financial Review Determinants of Exports Competitiveness: An Empirical Analysis Through Revealed Comparative Advantage of External Sector of Pakistan Keywords. 6(3), 623-633.

Sujjapongse, S. (2005). Tax Policy and Reform in Asian Countries: Thailand's Perspective. Journal of Asian Economics, 16(6), 10121028.

Usman, R. (2017). Pengaruh Pajak Daerah dan Retribusi Daerah Terhadap Pendapatan Asli Daerah (PAD). JAF-Journal of Accounting and Finance, 1(01), 87-103.

Vu, H. T., \& Pham, L. C. (2016). A Dynamic Approach to Assess International Competitiveness of Vietnam's Garment and Textile Industry. SpringerPlus, 5(1), 1-13.

Worumi, H. (2019). Model Strategi Peningkatan Pendapatan Asli Daerah Kabupaten Sarmi Provinsi Papua. Jurnal Ekologi Birokrasi, 6(3), 23-39. 